\title{
Use It or Lose It: State Approaches to Increasing Use-Tax Revenue
}

\section{INTRODUCTION}

The Internet has only existed in its current, recognizable form for around twenty years. During this brief period, the Internet has completely changed the way society operates. From buying goods and services to finding a companion, the Internet has forever altered human interaction. One of its most significant advances is undoubtedly the rise of electronic commerce, or e-commerce. E-commerce allows purchasers and sellers to conduct transactions across thousands of miles, often with each party unaware of the other's identity. This lack of physical contact, a hallmark of e-commerce, is markedly different than most brick-andmortar businesses.

In 1999, e-commerce sales totaled almost $\$ 1$ trillion. ${ }^{1}$ Just seven years later, that number ballooned to almost $\$ 2.5$ trillion. $^{2}$ E-commerce sales show no sign of slowing down; some analysts estimate sales will increase to $\$ 4$ trillion in 2012. ${ }^{3}$ While the expansion of the Internet and e-commerce has been a blessing for some businesses, this trend has caused many states and localities to become concerned over lost sales-tax revenues. ${ }^{4}$ With most e-commerce sales coming from remote sellers-or entities, businesses, or individuals that lack a material physical presence within a taxing jurisdiction ${ }^{5}$ - the majority of these sales avoid state and

* Joel Griffiths. J.D. candidate 2012, University of Kansas School of Law; B.S. 2008, Emporia State University. I first would like to thank the Kansas Law Review board and staff for all the work they have put in during the editing process. Specifically, I would like to thank Evan Jarrold, a great Articles Editor and a better person; Eli Rosenberg, the best proofing partner I could ask for; and Colin Baumchen, because without his smile, the fifth floor would not be the same. Also, I would like to thank Professor Martin Dickinson for his thorough review in the early stages of this paper. Further, I would like to thank Bill Self and the Kansas Jayhawks men's basketball team for giving me something to do other than work on law school. Finally, I thank Tom Treinen and Will Manly for helping me balance the rigors of law school with demands of an active social life.

1. Donald Bruce, William F. Fox \& LeAnn Luna, State and Local Sales Tax Revenue Losses from E-Commerce, 52 ST. TAX NOTES 537, 538 (2009).

2. Id.

3. Id.

4. Id.

5. This definition parallels the one used by the Streamlined Sales Tax Project. Frequently 
local sales taxes. ${ }^{6}$ Furthermore, e-commerce replaces transactions made through local, brick-and-mortar stores that are subject to sales tax. The current poor economic climate only increases states' worries about their ability to maintain or increase tax revenues.

Sales taxes are consumption-type taxes, which are "commonly understood to be a tax on the sale of tangible personal property."7 Businesses collect sales taxes at the point of sale and remit the collected funds to the appropriate taxing authority. ${ }^{8}$ The payment of sales tax is always the responsibility of the purchaser. ${ }^{9}$ In the United States, for fiscal year 2008, states and localities relied on sales taxes for almost $23 \%$ of total revenue. ${ }^{10}$ Because sales taxes play a large role in state and local budgets, the possibility of collecting tax from online and interstate transactions remains a hotly debated issue. The complexity and nonuniformity of the current sales tax system, however, makes it difficult for states to collect taxes from remote sellers. ${ }^{11}$ Currently, 8,000 different taxing jurisdictions exist in the United States-each with their own bases, rates, and exemptions. ${ }^{12}$ Additionally, the jurisdictions are not easily identifiable, as they do not even coincide with normally recognizable boundaries — such as five- or nine-digit zip codes. ${ }^{13}$

States have long had the power to tax transactions that transcend state boundaries. States exercise this power through use taxes, which

Asked Questions, STREAMLINED SALES TAX GOV’G BD., INC., http://www.streamlinedsalestax.org/ index.php?page=faqs (last visited Nov. 3, 2011).

6. Bruce, Fox \& Luna, supra note 1, at 542 (estimating "that taxes are uncollected on a little more than 4 percent of e-commerce").

7. 68 AM. JUR. 2D Sales and Use Tax $\S 1$ (2010) (citing Mr. B’s, Inc. v. City of Chicago, 706 N.E.2d 1001, 1005 (Ill. App. Ct. 1998)).

8. See id. A sales tax "is separately stated and collected on a transaction-by-transaction basis from the consumer; although the economic burden of the sales tax falls upon the consumer, the seller has the statutory duty to collect the tax for the taxing jurisdiction.” Id. (citing CHARLES A. TROST \& Paul James Hartman, Federal Limitations on State and Local Taxation § 11.1 (2d ed. 2003)).

9. See id. (citing Trost \& HARTMAn, supra note 9, § 11.1).

10. Kail Padgitt \& Ryan Forster, Where Do State and Local Governments Get Their Tax Revenue?, TAX FOUND. (Aug. 27, 2010), http://www.taxfoundation.org/research/show/26662.html. This does not include the amount collected from excise or selective taxes-such as those taxes collected on tobacco and alcohol—which accounted for an estimated $11 \%$ of revenue for states and localities in 2008. Id.

11. Joseph Henchman, Nearly 8,000 Sales Taxes and 2 Fur Taxes: Reasons Why the Streamlined Sales Tax Project Shouldn't Be Quick to Declare Victory, TAX Found. (July 28, 2008), http://www.taxfoundation.org/blog/show/23423.html.

12. Joseph Henchman, Testimony Before Maryland Legislature on the Streamlined Sales Tax Project, TAX Found. (Feb. 18, 2009), http://www.taxfoundation.org/publications/ show/24346.html.

13. Henchman, supra note 11. 
complement sales taxes and are "imposed on the use of certain goods that are bought outside the taxing authority's jurisdiction." 14 Use taxes prevent residents from avoiding sales taxes by purchasing goods from states that do not have a sales tax. ${ }^{15}$ Currently, all forty-five states that levy a sales tax also levy a complementary use tax. ${ }^{16}$ Use taxes are a constitutional method of assessing tax liability on purchases from out-ofstate retailers; ${ }^{17}$ however, problems arise when states try to raise the historically low use-tax compliance rates to increase revenue.

The fact that such a large percentage of state and local revenues come from sales taxes-coupled with the boom of e-commerce over the last decade-has led states to pursue many avenues when trying to collect sales and use taxes related to those transactions. ${ }^{18}$ A study estimated that in 1999 alone-well before the e-commerce boom—states collected a total of $\$ 140$ million in sales and use taxes from business-toconsumer e-commerce transactions, but another \$525 million in potential sales and use taxes remained uncollected. ${ }^{19}$ The amount of uncollected sales and use tax for states and local governments related to e-commerce sales is "expected to grow from $\$ 8.6$ billion in 2010 . . to to $\$ 11.4$ billion in 2012." ${ }^{20}$ Taxes collected from e-commerce sales remain low because of individuals' noncompliance with the use $\operatorname{tax}^{21}$ businesses' unwillingness to cooperate with use-tax collection, ${ }^{22}$ a lack of a definite

14. BLACK’S LAW DiCTIONARY 1597 (9th ed. 2009); see also discussion infra Part II.A.

15. BLACK's LAW DiCTIONARY 1597 (9th ed. 2009).

16. AdVISORY COMM'N ON ELEC. COMMERCE, REPORT TO CONGRESS 13 (2000), available at http://govinfo.library.unt.edu/ecommerce/acec_report.pdf [hereinafter ACEC REPORT].

17. See Henneford v. Silas Mason Co., 300 U.S. 577, 582-83 (1937). “Things acquired or transported in interstate commerce may be subjected to a [nondiscriminatory] tax" on use or enjoyment. Id. at 582 (citing Wiloil Corp. v. Pennsylvania, 294 U.S. 169, 175 (1935); Cudahy Packing Co. v. Minnesota, 246 U.S. 450, 453 (1918); Brown-Forman Co. v. Kentucky, 217 U.S. 563, 575 (1910); Am. Steel \& Wire Co. v. Speed, 192 U.S. 500, 519 (1903); Woodruff v. Parham, 75 U.S. (8 Wall.) 123, 137 (1868)).

18. See discussion infra Part II.D.

19. See Untaxed Web Sales Cost States \$525 Million in 1999, NATION’s CitiEs WKLY., Mar. 13, 2000, at 2 (discussing JAMES MCQUIVEY \& GILLIAN DEMARTIN, FORRESTER RESEARCH, INC., StATES Lose HALF A BILliON IN TAXES TO WEB RETAIL (2000)).

20. Bruce, Fox \& Luna, supra note 1, at 540. The authors forecast a total of $\$ 52.1$ billion in lost state sales and use tax revenue over the six-year period from 2007 to 2012. Id.

21. See id. at 557-58.

22. See, e.g., Amazon.com LLC v. N.Y. State Dep’t of Taxation \& Fin., 877 N.Y.S.2d 842, 846 (Sup. Ct. 2009) (noting the company's argument that absent substantial nexus with New York, outof-state entities should be exempt from the state's use-tax collection), aff'd as modified, 913 N.Y.S.2d 129 (App. Div. 2010); see also discussion infra Part II.C.1. 
standard from either the Supreme Court ${ }^{23}$ or Congress, and the nonuniform sales- and use-tax systems that span the United States. ${ }^{24}$

Recently, states have attempted to solve the use-tax problem. In the absence of Congress's adopting a nationwide standard, states have struggled to find a constitutionally acceptable approach to increasing use-tax compliance and revenue. Three distinct solutions have developed: affiliate taxes, ${ }^{25}$ increased notification standards, ${ }^{26}$ and the Streamlined Sales Tax Project. ${ }^{27}$ Each approach offers a unique attempt to increase use-tax revenue while remaining within the boundaries of the law.

This Comment will explain each approach, evaluate each approach's constitutionality, and determine whether the approach will actually raise revenue. Part II of this Comment describes both the current status of use taxes and the states' approaches to increasing revenue therefrom. Part III begins by analyzing the constitutionality of each approach and continues with an assessment of the feasibility of state implementation. Finally, Part III concludes with a discussion of whether the respective approaches will actually achieve their goals: raising use-tax compliance and revenue.

\section{BACKGROUND}

\section{A. Use Taxes}

Use taxes are the main method employed by states to tax transactions that take place across state lines. Use taxes are constitutional so long as they are nondiscriminatory and compensating; they must equalize taxes on both locally produced and imported goods. ${ }^{28}$ A relatively simple example demonstrates how use taxes operate. Suppose a resident of State $A$-a state that imposes sales and use taxes at a rate of $10 \%$-goes to State $B-$ a state that has no sales tax-to buy a new widget. Unbeknown to most individuals, if this resident intends to bring the

23. See Quill Corp. v. North Dakota, 504 U.S. 298, 316-17 (1992) (noting the legal “quagmire” in this area (quoting Nw. States Portland Cement Co. v. Minnesota, 358 U.S. 450, 457-58 (1959)) (internal quotation marks omitted)).

24. See Henchman, supra note 11.

25. See infra Part II.D.1.

26. See infra Part II.D.2.

27. See infra Part II.D.3.

28. See Henneford v. Silas Mason Co., 300 U.S. 577, 582-84 (1937) (upholding a Washington use tax that provided an offset if the object had been subject to an equivalent use or sales tax in the state of purchase). 
widget back into State $A$ and use it there, then he must pay State $A$ 's use tax. The amount due is the sales tax that the resident would owe if he purchased the widget in State $A-10 \%$ of the purchase price-less the tax he paid in State $B$. Since State $B$ imposes no sales tax, the resident will owe State $A$ a use-tax equivalent to $10 \%$ of the purchase price. Thus, if the resident bought the widget for $\$ 1,000$, then he would owe $\$ 100$ in use tax to State $A$. Further, even if State $B$ had a sales tax, the resident of State $A$ would have a use-tax liability in State $A$ so long as the sales tax charged in State $B$ was less than $10 \%$. In a situation in which State $B$ 's sales tax rate was $4 \%$, the resident of State $A$ would have usetax liability in State $A$ for the remaining $6 \%$ of the purchase price.

As the hypothetical shows, use taxes are often hard to calculate and even harder to enforce. "States have historically viewed the use tax on individuals as impractical to enforce-the tax typically involves a small amount owed on a large number of transactions for which the individual has not kept records, and the costs of collection could easily exceed the revenues collected." 29 This has led to low use-tax compliance in business-to-consumer sales. ${ }^{30}$ Another reason the collection rates are low "is that taxing agencies have no practical means of identifying individual purchases or their consumers, making enforcement difficult." ${ }^{31}$ Use-tax collection is high, however, in business-to-business transactions because the businesses are subject to audits and often have a better understanding of the law. ${ }^{32}$ Individuals do have higher use-tax compliance when purchasing automobiles from out-of-state sellers. ${ }^{33}$ The increased collection rate likely occurs because the individual's state of residence will not register the car until the purchaser pays the use tax. The historically low use-tax compliance rates of individuals is an issue that all three approaches discussed in Part II.D seek to address; it remains to be seen if any approach can remedy the problem.

\section{B. Setting the Stage: Quill Corp. v. North Dakota}

In Quill Corp. v. North Dakota, the United States Supreme Court developed and applied the current approach to use-tax collection from

29. Nina Manzi, Use Tax Collection on Income Tax Returns in Other States, at 4 (Minn. 2010), available at http://www.house.leg.state.mn.us/hrd/pubs/usetax.pdf.

30. ACEC REPORT, supra note 16 , at 13.

31. Id.

32. Id. at $13-14$

33. Bruce, Fox \& Luna, supra note 1, at 553. 
remote sellers. ${ }^{34}$ The case centered on a North Dakota law that required every retailer that maintained a place of business in the state to collect and remit a use tax. ${ }^{35}$ The statute defined a retailer as anyone "who engage[d] in regular or systematic solicitation" within the state. "State regulations in turn define[d] 'regular or systematic solicitation' to mean three or more advertisements within a [twelve]-month period." ${ }^{\text {37 }}$ The law, in effect, required all businesses that advertised in North Dakota to collect and remit the use tax. ${ }^{38}$ Quill was a Delaware corporation with no employees, offices, or tangible property within North Dakota. ${ }^{39}$ Quill's solicitation of business in North Dakota through "catalogs and flyers, advertisements in national periodicals, and telephone calls" ${ }^{40}$ subjected it to the law's requirements. ${ }^{41}$ The Supreme Court held that requiring Quill to collect the use tax violated the Dormant Commerce Clause. ${ }^{42}$ The Court rejected previous decisions by stating that the Due Process Clause did not bar the enforcement of North Dakota's law. ${ }^{43}$ The Court wrote that "Quill has purposefully directed its activities at North Dakota residents[ and] that the magnitude of those contacts is more than sufficient for due process purposes." ${ }^{44}$ Thus, because the law related to benefits that Quill received from North Dakota, it satisfied the due process analysis. ${ }^{45}$

The case turned on the Dormant Commerce Clause, with the Court reaffirming a four-part test to determine the constitutionality of a tax:

\footnotetext{
34. See Quill Corp. v. North Dakota, 504 U.S. 298, 317-18 (1992) (upholding bright-line test).

35. Id. at 302 .

36. Id. at 302-03 (quoting N.D. CENT. CODE § 57-40.2-01(6) (Supp. 1991)) (internal quotation marks omitted).

37. Id. at 303 (citing N.D. ADMIN. CODE 81-04.1-01-03.1 (1988)).

38. Id. (citing N.D. CENT. CODE § 57-40.2-07).

39. Id. at 302 .

40. Id.

41. Id. at 303.

42. Id. at 309-19.

43. Id. at 305-08. While the Court conceded that the Commerce Clause and Due Process Clause were similar, it noted that "the Clauses pose distinct limits on the taxing powers of the States.” Id. at 305. The Court decided to

[A]bandon[] more formalistic tests that focused on a defendant's "presence" within a State in favor of a more flexible inquiry into whether a defendant's contacts with the forum made it reasonable, in the context of our federal system of Government, to require it to defend the suit in that State.

Id. at 307 .

44. Id. at 308 .

45. Id.
} 
[The Supreme Court] will sustain a tax against a Commerce Clause challenge so long as the "tax [1] is applied to an activity with a substantial nexus with the taxing State, [2] is fairly apportioned, [3] does not discriminate against interstate commerce, and [4] is fairly related to services provided by the State." 46

As was the case in Quill, the "substantial nexus" requirement causes most modern disputes regarding use-tax collection. While the Court explicitly noted that the Dormant Commerce Clause requires a "substantial nexus" between a taxing jurisdiction and remote seller, it did nothing more than give an example of what did not constitute a substantial nexus: contacts by a common carrier. ${ }^{47}$ Thus, as was the case with Quill, when a business's only contact with a state comes through mail advertisements and remote sales, the state cannot require use-tax collection from that business. ${ }^{48}$ The Court held that the law discriminated against, or unduly burdened, interstate commerce. ${ }^{49}$ This burden arose because different taxing jurisdictions" "many variations in rates of tax, in allowable exemptions, and in administrative and recordkeeping requirements could entangle [a remote seller] in a virtual welter of complicated obligations." ${ }^{\text {"50 }}$ Even though the Court declared the North Dakota law unconstitutional, it recognized that the legal system must address the use-tax problem.

The Court in Quill reiterated that Congress had the ability to overrule its decision. ${ }^{51}$ By doing away with the due process argument, the Court opened the door for Congress to legislate, ${ }^{52}$ stating that "Congress is now free to decide whether, when, and to what extent the States may burden interstate mail-order concerns with a duty to collect use taxes." 53 This suggestion was not novel, as the Court had previously stated that "[i]t is clear that the legislative power granted to Congress by the Commerce

46. Id. at 311 (quoting Complete Auto Transit, Inc. v. Brady, 430 U.S. 274, 279 (1977)).

47. Id. at 311-12.

48. Id. at 312 .

49. See id. at 318-19.

50. Id. at 313 n.6 (quoting Nat'l Bellas Hess, Inc. v. Dep’t of Revenue, 386 U.S. 753, 759-60 (1967)) (internal quotation marks omitted).

51. Id. at 318 .

52. John A. Swain, State Sales and Use Tax Jurisdiction: An Economic Nexus Standard for the Twenty-First Century, 38 GA. L. REV. 343, 364 (2003).

53. Quill, 504 U.S. at 318. The Court further explained that "the underlying issue is not only one that Congress may be better qualified to resolve, but also one that Congress has the ultimate power to resolve. No matter how we evaluate the burdens that use taxes impose on interstate commerce, Congress remains free to disagree with our conclusions." Id. (footnote omitted) (citing Prudential Ins. Co. v. Benjamin, 328 U.S. 408 (1946)). 
Clause of the Constitution would amply justify the enactment of legislation requiring all States to adhere to uniform rules for the division of income." ${ }^{54}$ In the eighteen years since the Quill decision, however, Congress has not taken action, ${ }^{55}$ thus leaving it up to the states to find a solution. Several states have taken steps to increase use-tax revenues, as evidenced by the different approaches analyzed by this Comment.

While the Quill decision created the ambiguous standard requiring a "substantial nexus," the states brought this standard upon themselves. ${ }^{56}$ The inordinate amount of taxing jurisdictions likely led the Court to feel "compelled to protect the constitutional guarantee of an open market for domestic goods from the threat of diminished interstate trade that would result from rules so cumbersome in their multiplicity." 57 "[T] seems to have left businesses dealing in interstate commerce more vulnerable to tax attacks .... [On the other hand, it] may have left the door open for businesses to argue that 'substantial nexus' requires physical presence." 58 Without a definite standard, states are unsure of their ability to tax remote sellers and, in response, have developed many innovative approaches. ${ }^{59}$ The Court in Quill noted that, "with certain restrictions, interstate commerce may be required to pay its fair share of state taxes," ${ }^{60}$ which at least keeps open the possibility that remote sellers may face use-tax liability.

54. Moorman Mfg. Co. v. Bair, 437 U.S. 267, 280 (1978).

55. While legislators have introduced such simplifying legislation, Congress has not enacted any of the proposals. See Sales Tax Fairness and Simplification Act, H.R. 3396, 110th Cong. (2007); Streamlined Sales Tax Simplification Act, S. 2153, 109th Cong. (2005); Streamlined Sales and Use Tax Act, S. 1736, 108th Cong. (2003); Streamlined Sales and Use Tax Act, H.R. 3184, 108th Cong. (2003); Internet Tax Moratorium and Equity Act, S. 512, 107th Cong. (2001).

56. Brian Galle, Designing Interstate Institutions: The Example of the Streamlined Sales and Use Tax Agreement ("SSUTA"), 40 U.C. DAVIS L. REV. 1381, 1387 (2007) (arguing that the Supreme Court limited states' authority to collect sales and use taxes from non-local sellers in large part because of "states' irresponsibility in allowing a bewildering array of state and local sales tax rules to develop”).

57. Id.

58. Christina T. Le, Comment, The Honeymoon's Over: States Crack Down on the Virtual World's Tax-Free Love Affair with E-Commerce, 7 Hous. Bus. \& TAX L.J. 395, 407-08 (2007) (citing Quill, 504 U.S. at 314). As one commentator observed, "[i]nstead of providing a concrete test for states and businesses to determine when 'substantial nexus' exists, the ruling has only opened myriad uncertainties and confusion about taxation of interstate commerce.” Id. at 407.

59. See infra Part II.D.

60. Quill, 504 U.S. at 310 n.5 (quoting D.H. Holmes Co. v. McNamara, 486 U.S. 24, 31 (1988)) (internal quotation marks omitted). As the Court has explained "[i]t was not the purpose of the [C]ommerce [C]lause to relieve those engaged in interstate commerce from their just share of state tax burden even though it increases the cost of doing business." Commonwealth Edison Co. v. Montana, 453 U.S. 609, 623-24 (1981) (first alteration in original) (quoting Colonial Pipeline Co. v. Traigle, 421 U.S. 100, 108 (1975)) (internal quotation marks omitted). 


\section{Problems Arising from the Application of Quill}

\section{Entity Isolation}

The Supreme Court in Quill attempted to set out a bright-line rule to calm the uneasy waters of use-tax liability. ${ }^{61}$ Despite the good intentions of the Court, its adoption of the "substantial nexus" standard has led to undesirable results. Many businesses now engage in the practice of entity isolation to avoid creating a "substantial nexus" with the taxing jurisdiction. Entity isolation "involves a relatively simple restructuring: isolate the firm's remote sales operations in a legal entity that is separate from the legal entity that holds the firm's store operations."62 When done correctly, the distinct legal entity erodes the original business's substantial nexus with the state, and the business avoids the responsibility of collecting sales and use taxes. ${ }^{63}$ The business must take care to ensure that the remote-selling division of the business is distinct-in both reality and substance-from the physically present entity in order to avoid use-tax liability. ${ }^{64}$

Several large companies have attempted to gain the benefits of entity isolation, and some have succeeded-most notably the online retailer Amazon.com. ${ }^{65}$ Amazon has leased facilities in at least nineteen states $^{66}$ - which presumably provides those states with the requisite substantial nexus_-"but it pays sales taxes in only five of them., ${ }^{, 67}$ Further, while Amazon asserts that collecting use taxes would be unduly burdensome, Amazon "already calculates and collects sales tax in at least 44 of the 45 states that levy them for independent companies that

61. Quill, 504 U.S. at 315-16.

62. Mark J. Cowan, Tax Planning Versus Business Strategy: The Rise and Fall of Entity Isolation in Sales and Use Taxes, 44 IDAHO L. REV. 63, 65 (2007).

63. Le, supra note 58, at 409.

64. See Walter Baudier, Note, Internet Sales Taxes from Borders to Amazon: How Long Before All of Your Purchases Are Taxed?, 2006 DukE L. \& TECH. REV. no. 5, ๆ 9 -10 (2006) (discussing Borders Group's failure to sufficiently separate its online and brick-and-mortar divisions).

65. See Michael R. Gordon, Comment, Up the Amazon Without a Paddle: Examining Sales Taxes, Entity Isolation, and the “Affiliate Tax", 11 N.C. J.L. \& TECH. 299, 306-07 (2010). This Comment will often refer to Amazon and its business practices. Given Amazon's status as the largest online retailer, its many attempts at avoiding liability for use-tax collection, and the ingenious ways it has tried to achieve this, Amazon provides a particularly apt example.

66. Id. at 307.

67. Id. (citing Randall Stross, Sorry, Shoppers, but Why Can't Amazon Collect More Tax?, N.Y. TiMES, Dec. 27, 2009, at BU3). 
sell their merchandise on Amazon's website."68 Amazon would likely face minimal administrative burdens if it had to collect use tax for its own sales. In contrast, small online retailers that only sell their own products and do not have a method in place to calculate and collect use taxes face a larger burden. Any state that wishes to tax remote sellers must be cognizant of the problems caused by entity isolation. Every approach discussed in this Comment addresses entity isolation in its own way.

\section{Unfair Burdens Placed on Physically Present Businesses}

While many online retailers may claim that new use-tax laws discriminate against interstate commerce, the new laws actually appear to level the playing field between remote sellers and retailers who must collect sales and use taxes. This occurs because of the lack of awareness of the use tax by individual consumers. Therefore, whether a purchase occurs in a physical store or through an online retailer, the same sales tax applies - or the complementary use tax, in the case of a remote sale. While many consumers purchase products online for better deals, remote sellers only use a façade of lower prices; "[b]ecause the purchaser has to pay an identical use tax to the state, the price is not actually any lower except to the lawbreaker who does not pay the tax." ${ }^{\text {"9 }}$ The reality of the lower prices that online retailers advertise is that the burden of collecting the tax is passed from the business - which often will have the necessary procedures in place to determine tax liability — to the individual—who is often unaware the use-tax liability even exists.

Another factor that shows the unfairness of the current system is that many large retailers that maintain both online retail websites and physical businesses within a state must collect use taxes on all remote sales, even though the purchases may have little connection to the instate physical store. ${ }^{70}$ "Walmart, Barnes \& Noble, and Best Buy, for example, manage to collect sales tax on their Internet sales in every state in which they have a retail store."71 It is likely that these companies could advance many of the same frivolous arguments-the compliance

68. Michael Mazerov, Ctr. on Budget \& Policy Priorities, Amazon's Arguments Against Collecting SAles TAXes Do Not Withstand SCRutiny 4 (Nov. 29, 2009), available at http://www.cbpp.org/files/11-16-09sfp.pdf.

69. Gordon, supra note 65, at 315 (footnote omitted).

70. MAZEROV, supra note 68 , at 5.

71. Id. 
and administrative costs are unduly burdensome-that several remote sellers do. As the Supreme Court has held, "[i]t was not the purpose of the [C]ommerce [C]lause to relieve those engaged in interstate commerce from their just share of state tax burden even though it increases the cost of doing business." 72 This undermines the argument that administrative burdens caused by use-tax collection on remote sellers are excessive. The Court's holding in Quill, however, allows businesses without a substantial nexus to avoid use-tax collection and, thus, inspires states to develop their own approaches to collect the taxes.

\section{State Approaches to Collecting Sales and Use Taxes from Remote Sellers and Purchasers}

\section{Affiliate Taxes}

With almost every state facing budget shortfalls and economic problems, some states have taken an aggressive approach to collecting use taxes from remote sellers by implementing affiliate tax laws. ${ }^{73}$ The New York affiliate law presumes that a remote seller does business within New York when:

[T] he seller enters into an agreement with a resident of [New York] under which the resident, for a commission or other consideration, directly or indirectly refers potential customers, whether by a link on an internet website or otherwise, to the seller, if the cumulative gross receipts from sales by the seller to customers in the state who are referred to the seller by all residents with this type of an agreement with the seller is in excess of ten thousand dollars during the preceding four quarterly periods ....

These laws directly combat Internet retailers who refuse to collect and remit use taxes. ${ }^{75}$ "While [twenty-one] states have considered 'Amazon' laws in the past three years, only seven have enacted them: Arkansas, California, Connecticut, Illinois, New York, North Carolina, and Rhode

\footnotetext{
72. Colonial Pipeline Co. v. Traigle, 421 U.S. 100, 108 (1975) (quoting W. Live Stock v. Bureau of Revenue, 303 U.S. 250, 254 (1938)) (internal quotation marks omitted).

73. Joseph Henchman, "Amazon Tax" Laws Signal Business Unfriendliness and Will Worsen Short-Term Budget Problems, TAX FounD. (Mar. 8, 2010), http://taxfoundation.org/news/show/ 25949.html. Such laws have earned many different names, including affiliate taxes, affiliate nexus taxes, and Amazon taxes. Id.

74. N.Y. TAX LAW § 1101(b)(8)(vi) (McKinney Supp. 2012).

75. Gordon, supra note 65, at 309; see also supra Part II.C.1.
} 
Island."76 The reaction to affiliate laws varies, and some opponents have claimed that they are unconstitutional. ${ }^{77}$ The response by businesses has been harsh, including Amazon's cutting all of its ties with affiliates in several states, including Colorado, North Carolina, and Rhode Island. ${ }^{78}$

The New York affiliate law-which is very similar to the laws in both North Carolina and Rhode Island-has several safeguards in place to ensure that a "substantial nexus" exists. ${ }^{79}$ New York's law deems a company to have a rebuttable presumption of physical presence in the state- thus satisfying the substantial nexus requirement of $Q u i l l^{80}$ —if the remote seller paid an independent contractor with a New York address for referring customers to its website and those referred transactions resulted in sales of over $\$ 10,000$ to New York residents. ${ }^{81}$ The law is broad in that if only one affiliate refers over $\$ 10,000$ in sales, then the remote seller must collect use taxes on all sales made to New York residents. ${ }^{82}$ Thus, a remote seller could have only one affiliate in the state, and so long as that one affiliate refers enough sales, the remote seller will be liable for collecting the use tax on all sales to New York residents and not just sales referred through affiliates. ${ }^{83}$

"This presumption may be rebutted by proof that the resident with whom the seller has an agreement did not engage in any solicitation in the state on behalf of the seller that would satisfy the nexus requirement of the United States [C]onstitution during the four quarterly periods in

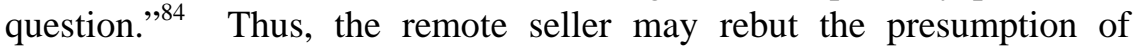
physical presence-and, accordingly, the substantial nexus requirement-by "includ[ing] in its agreement a condition that in-state commissioned representatives are prohibited from engaging in solicitation activities in New York on its behalf and ensur[ing] compliance through a certification." ${ }^{85}$ This provision allows remote

76. Joseph Henchman, California Becomes Seventh State to Adopt “Amazon" Tax on Out-ofState Online Sellers, TAX Found. (July 1, 2011), http://www.taxfoundation.org/news/show/ 27416.html.

77. See Henchman, supra note 73.

78. Verne G. Kopytoff, Amazon Pressured on Sales Tax, N.Y. TimES, Mar. 14, 2011, at B1.

79. N.Y. TAX LAW § 1101(b)(8)(vi). Because the affiliate laws of North Carolina and Rhode Island are similar enough to New York's law, a separate discussion of each is unwarranted.

80. Quill Corp. v. North Dakota, 504 U.S. 298, 313-14 (1992).

81. N.Y. TAX LAW § 1101(b)(8)(vi).

82. Id.

83. Id.

84. Id.

85. Amazon.com LLC v. N.Y. State Dep’t of Taxation \& Fin., 877 N.Y.S.2d 842, 846 (Sup. Ct. 2009), aff'd as modified, 913 N.Y.S.2d 129 (App. Div. 2010). 
sellers to avoid use-tax collection. Therefore, the law takes care not to place collection burdens on those businesses that lack a substantial nexus. Not surprisingly, New York's affiliate law faced a constitutional challenge almost immediately, with results that may change the landscape of use taxes. ${ }^{86}$

\section{The Increased-Notification Approach}

Colorado enacted into law House Bill No. 10-1193 on February 24, $2010 .^{87}$ This new law is an effort by Colorado to increase reporting and notification requirements, with the hope of increasing use-tax compliance by individuals. ${ }^{88}$ The Colorado law gives remote sellers a choice: either collect use taxes on Colorado purchases or notify the purchaser that use tax is due on purchases made from that retailer. ${ }^{89}$ Further, if the remote seller does not collect the tax, then it must include a notification to the buyer stating that Colorado requires the purchaser to file a use-tax return. ${ }^{90}$ This notification must accompany every purchase from a non-collecting retailer. ${ }^{91}$ Colorado regulations prescribe the required contents of such notice, which must inform the purchaser that:

(i) The non-collecting retailer does not collect Colorado sales or use tax;

(ii) The purchase is not exempt from Colorado sales or use tax merely because it is made over the Internet or by other remote means;

(iii) The State of Colorado requires that a Colorado purchaser (A) files a sales or use tax return at the end of the year reporting all of the taxable Colorado purchases that were not taxed and (B) pay tax on those purchases.

86. Id. at $846,849-51$.

87. Act of Feb. 24, 2010, ch. 9, § 2, 2010 Colo. Sess. Laws 54 (codified at Colo. Rev. STAT. ANN. § 39-21-112 (3.5)(c)(I) (West Supp. 2011)). It is of note that a Colorado judge granted a preliminary injunction that, in effect, prevents Colorado from enforcing the relevant parts of its law. Direct Mktg. Ass'n v. Huber, No. 10-cv-01546-REB-CBS, 2011 WL 250556, at *1-6 (Jan. 26, 2011). Oklahoma also implemented a similar notification law, but it is much less stringent than Colorado’s law. See OKLA. STAT. ANN. tit. 68, § 1406.1 (West Supp. 2011).

88. See Colo. Rev. StAT. ANN. § 39-21-112 (3.5)(c)(I).

89. Id.

90. Id.

91. Id.

92. COLO. CODE REGS. § 39-21-112.3.5(2)(b) (2012). 
In addition to the notification required for every purchase, remote sellers that ship goods to Colorado addresses must also send annual notifications to the Colorado purchasers. ${ }^{93}$ These annual "notification[s] shall include, if available, the dates of purchases, the amounts of each purchase, and the category of the purchase, including, if known by the retailer, whether the purchase is exempt or not exempt from taxation."94 The notification must state that "Colorado requires a sales or use tax return to be filed and sales or use tax paid on certain Colorado purchases made by the purchaser from the retailer."95 Further, the non-collecting retailers must also send an annual statement to the Colorado Department of Revenue. ${ }^{96}$ This statement must include the total amount each Colorado consumer purchased from that non-collecting retailer during the preceding calendar year. ${ }^{97}$ Colorado's new law differs from all of the other approaches because it gives remote sellers an option: collect and remit the use tax due or send the required notifications. The law is the only of the three approaches that puts pressure on the end consumer instead of the remote seller.

\section{Streamlined Sales Tax Project}

The Streamlined Sales Tax Project (SSTP) formally launched in 2000 as a collaborative effort among several states. ${ }^{98}$ This collaboration produced the Streamlined Sales and Use Tax Agreement (SSUTA). ${ }^{99}$ The SSUTA intends to "simplify and modernize sales and use tax administration in order to substantially reduce the burden of tax compliance." 100 Twenty-four states, whose populations represent 33\% of the United States' total population, have adopted the SSUTA. ${ }^{101}$ The SSUTA attempts to reduce the compliance and administrative burdens of the use tax-one of the main reasons the Quill court ruled against use-tax collection $^{102}$ - so that states can require remote sellers to figure, collect,

93. Colo. Rev. STAT. ANN. § 39-21-112(3.5)(d)(I)(A).

94. Id.

95. Id.

96. Id. § 39-21-112(3.5)(d)(II)(A)

97. Id.

98. About Us, StREAmLined SALES TAX GOV’G BD., INC., http://www.streamlinedsalestax.org/ index.php?page=About-Us (last visited Nov. 6, 2011).

99. Id.

100. Id.

101. Frequently Asked Questions, supra note 5.

102. Quill Corp. v. North Dakota, 504 U.S. 298, 313 (1992). 
and remit use taxes. The SSTP and SSUTA differ from the other approaches because Congress needs to pass legislation requiring all states to be full members; ultimately, the SSTP anticipates federal legislation authorizing state sales and use-tax collection from remote sellers catalyzed by the SSUTA's simplification of tax administration. ${ }^{103}$ The SSTP and SSUTA are a response to the Court in Quill, ${ }^{104}$ which, reiterating Dormant Commerce Clause doctrine, left open Congress's ability to reverse its decision. ${ }^{105}$ Without action by Congress, the SSTP and SSUTA will fail to increase use-tax revenue for member states. ${ }^{106}$

The SSUTA attempts to achieve its goals of simplicity and uniformity in several ways. One way is that the SSUTA requires members to utilize a "Library of Definitions" for products that a jurisdiction may potentially subject to tax. ${ }^{107}$ For example, until recently, states did not even have a uniform definition of candy. ${ }^{108}$ These nonuniform definitions only add to the complexity of use taxes and increase the burdens on remote sellers. The SSUTA also limits a state's ability to tax an item contained in the library unless the state uses the prescribed definition. ${ }^{109}$ When a state wishes to tax an item, "[it] must then establish a tax 'matrix' in which [it] check[s] off which of the library items [it] will tax." "110 The SSUTA also limits the number of tax rates a state can have, including those rates imposed by counties and localities. ${ }^{111}$ A state desiring to join the SSTP must prove substantial compliance with the current SSUTA. ${ }^{112}$ While the SSTP and SSUTA have gained acceptance, several attempts at passing federal legislation have failed. ${ }^{113}$ This illustrates the major flaw of the SSTP: without

103. See Frequently Asked Questions, supra note 5 (describing how the simplification of sales and use-tax administration, as proposed by the SSUTA, lays the groundwork for congressional action).

104. See About Us, supra note 98.

105. Quill, 504 U.S. at 318.

106. Frequently Asked Questions, supra note 5.

107. STREAMLINED SALES AND USE TAX AgREEMENT (SSUTA) § 327 (2011), available at http://www.streamlinedsalestax.org/uploads/downloads/Archive/SSUTA/SSUTA\%20AS\%20Amend ed\%2005-19-11.pdf.

108. Henchman, supra note 12.

109. Galle, supra note 56, at 1393 (citing SSUTA § 304).

110. Id. (footnote omitted).

111. See id. at 1393 (citing SSUTA § 308).

112. SSUTA §§ 804, 805.

113. See Sales Tax Fairness and Simplification Act, H.R. 3396, 110th Cong. (2007); Streamlined Sales Tax Simplification Act, S. 2153, 109th Cong. (2005); Streamlined Sales and Use Tax Act, S. 1736, 108th Cong. (2003); Streamlined Sales and Use Tax Act, H.R. 3184, 108th Cong. (2003); Internet Tax Moratorium and Equity Act, S. 512, 107th Cong. (2001). 
congressional action, the SSTP will not achieve its overarching goaldecreasing burdens on use-tax compliance and, therefore, increasing usetax revenues for states.

\section{ANALYSIS}

\section{A. Due Process Analysis of State Approaches}

The Fifth and Fourteenth Amendments to the U.S. Constitution lay out the Due Process Clauses. These Clauses combine to protect citizens from deprivation of "life, liberty, or property, without due process of law." 114 Due process, as applied to the states' abilities to tax interstate transactions, has gone through many changes over the years. ${ }^{115}$ The Quill Court, however, laid out a standard ${ }^{116}$ that has survived for the last two decades. ${ }^{117}$ While a due process challenge is easier to withstand than a Dormant Commerce Clause challenge, it still warrants discussion.

In Quill, the Court backed off the physical-presence standard that had dominated the due process tax analysis for many years, replacing it with standards concerned with "fundamental fairness."118 The Court stated that due process was more of a "flexible inquiry into whether a defendant's contacts with the forum made it reasonable ... to require it to defend the suit in that State."119 The Court took the test for due process indirectly from the personal jurisdiction analysis, affirming that a business that "purposefully avails" itself of a market is subject to jurisdiction in the state, even without physical presence. ${ }^{120}$ Thus, the

114. U.S. CONST. amend. V; U.S. ConST. amend. XIV, § 1.

115. See Quill Corp. v. North Dakota, 504 U.S. 298, 306-08 (1992) (discussing prior Supreme Court decisions regarding the due process limitations on states' taxation of transactions in interstate commerce).

116. Id. at 312-13 (1992).

117. Red Earth LLC v. United States, 728 F. Supp. 2d 238, 247-48 (W.D.N.Y. 2010) (applying the Quill due process standard to state taxes levied on an out-of-state seller).

118. Quill, 504 U.S. at 312.

119. Id. at 307.

120. Id. As the Court had previously explained in the context of personal jurisdiction, the consideration requires a multi-part analysis:

Thus where the defendant "deliberately" has engaged in significant activities within a State or has created "continuing obligations" between himself and residents of the forum, he manifestly has availed himself of the privilege of conducting business there, and because his activities are shielded by “the benefits and protections" of the forum's laws it is presumptively not unreasonable to require him to submit to the burdens of litigation in that forum as well.

Burger King Corp. v. Rudzewicz, 471 U.S. 462, 475-76 (1985) (citations omitted) (quoting Keeton 
Quill Court found it appropriate-at least for due process purposes - that a state could require the business to collect and remit use taxes when it could properly subject the business to suit within the state. ${ }^{121}$

All the individual state approaches discussed in this Comment appear to satisfy due process by including a de minimis standard in their respective laws. For example, in New York, a remote seller must have entered into an agreement with a New York resident that resulted in the resident's referring more than $\$ 10,000$ in gross receipts to the seller before the law requires it to collect use taxes. ${ }^{122}$ The $\$ 10,000$ in gross sales must have been to consumers located in New York. ${ }^{123}$ This de minimis exception guarantees that the remote seller has directed "substantial" business toward the state through either an agreement with the in-state affiliate or sales made to consumers, thus satisfying the due process purposeful availment requirement. North Carolina's version of the affiliate tax law contains a de minimis exception of $\$ 10,000,{ }^{124}$ while Rhode Island's tax includes de minimis exception of $\$ 5,000 .{ }^{125}$ Colorado's increased notification law also contains a de minimis provision: the remote seller must have over $\$ 100,000$ in sales to Colorado purchasers before being subject to the law's requirements. ${ }^{126}$ All of these de minimis standards attempt to ensure that a remote seller required to collect taxes has purposefully directed its activities at a state, thus satisfying due process.

The Appellate Division of the New York Supreme Court recently held that New York's affiliate law, on its face, did not violate the Due Process Clause. ${ }^{127}$ Previously, the lower court had dismissed complaints alleging that the statute was unconstitutional under the Due Process Clause, the Commerce Clause, and the Equal Protection Clause. ${ }^{128}$ While the law survived all three facial challenges, the court remanded the

v. Hustler Magazine, Inc., 465 U.S. 770, 781 (1984); Travers Health Ass'n v. Virginia ex rel. State Corp. Comm'n, 339 U.S. 643, 648 (1950)).

121. Quill, 504 U.S. at 307-08 (rejecting Quill Corp.'s due process challenge to a North Dakota use tax because Quill "purposefully directed its activities" at residents, its contacts were sufficient in magnitude, and the tax "related to the benefits Quill receive[d] from access to the State").

122. N.Y. TAX LAW § 1101(b)(8)(vi) (McKinney Supp. 2012).

123. Id.

124. N.C. Gen. StAT. AnN. § 105-164.8(b)(3) (West Supp. 2010).

125. R.I. GEN. LAWS ANN. § 44-18-15(a)(2) (West Supp. 2011).

126. COLO. CODE REGS. § 39-21-112.3.5(1)(a)(iii) (2012).

127. Amazon.com, LLC v. N.Y. State Dep’t of Taxation \& Fin., 913 N.Y.S.2d 129, 139-41 (App. Div. 2010), aff'g as modified 877 N.Y.S.2d 842 (Sup. Ct. 2009).

128. Amazon.com, 877 N.Y.S.2d at 846. 
case because there was insufficient evidence to make a determination on the as-applied claims under the Commerce and Due Process Clauses. ${ }^{129}$ In regard to the due process challenge, the court first noted that the statute required remote sellers that solicited business in New York through affiliates to collect use taxes. ${ }^{130}$ The court implied that solicitation by affiliates establishes purposeful availment of New York for remote sellers. ${ }^{131}$ Next, the court found rational the law's presumption that affiliates would in fact solicit business, instead of merely advertising. ${ }^{132}$ The court deemed this presumption rational because it is the goal of both the affiliate and the remote seller to make money. ${ }^{133}$ To maximize earnings, at least some affiliates would engage in solicitation, thus invoking the law's requirements. ${ }^{134}$ Therefore, even absent a de minimis requirement, New York's law-and presumably other affiliate laws — did not facially violate the Due Process Clause.

By their design, the SSTP and SSUTA do not warrant due process analysis. The Court in Quill practically asked for the formation of the SSTP. ${ }^{135}$ The Court wrote that "Congress is now free to decide whether, when, and to what extent the States may burden interstate mail-order concerns with a duty to collect use taxes," which is a sign that the Due Process Clause does not prohibit Congress from imposing uniform use and sales tax laws throughout the country. ${ }^{136}$

Thus, the SSTP merely awaits congressional implementation, and it will not have to face due process challenge. The SSUTA, however, may run afoul of the essence of due process. First, due process asks whether a business purposefully avails itself of a state's market by taking advantage of the protections and rights that a state offers. ${ }^{137}$ The SSUTA, though, contains no de minimis exception or other requirement to guarantee that the business has purposefully directed its activities at a chosen state. Because many large businesses already have procedures in place to figure, collect, and remit use taxes, they will not realize significant

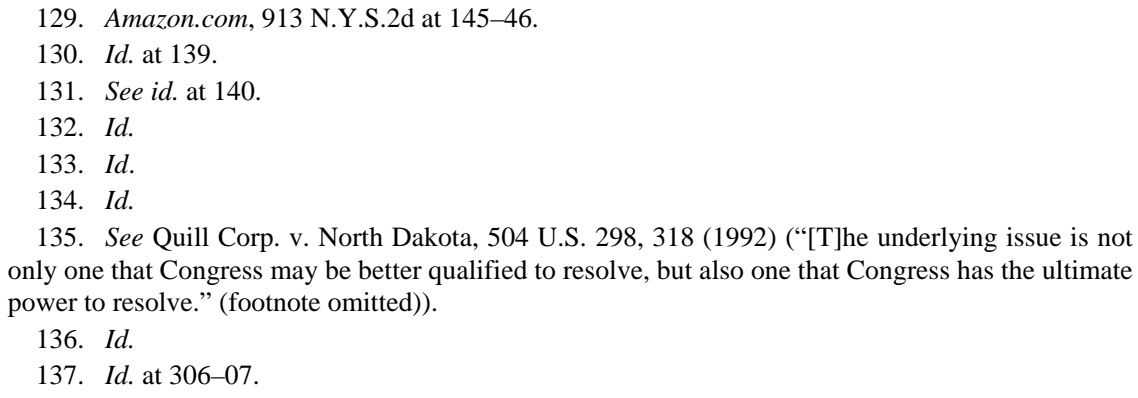


damage from the adoption of the SSUTA and congressional implementation of the SSTP. On the other hand, smaller businesseslikely taking advantage of fewer state benefits-will not have procedures in place to immediately deal with the law. Thus, while a large business-receiving many benefits from a state-can comply with the SSTP in a matter of hours, a small business will have to incur large costs and dramatic changes to comply with the new system. Even though a congressionally adopted SSTP will avoid due process challenge, it will not avoid the due process problems faced by the other approaches.

Every approach appears to withstand due process challenge-based in large part on the standards ensuring that a business "purposefully avails" itself of the state's market. As noted in Quill, however, due process will not often render a tax law unconstitutional. ${ }^{138}$ The law must also pass the more stringent Dormant Commerce Clause analysis.

\section{B. Dormant Commerce Clause Analysis of State Approaches}

The "Dormant" Commerce Clause is a legal doctrine inferred from the Commerce Clause in Article I of the U.S. Constitution. Because the Commerce Clause grants Congress the power to regulate commerce among the states, ${ }^{139}$ the negative inference is that the Clause bars states from imposing laws that improperly burden or discriminate against interstate commerce. ${ }^{140}$ The Court solidified the Dormant Commerce Clause's application to state taxes in Complete Auto Transit, Inc. v. Brady, ${ }^{141}$ and the Quill Court adopted this standard. ${ }^{142}$ In Complete Auto, the Court held that a state may require a remote seller to collect taxes on the state's behalf when the "tax is applied to an activity with a substantial nexus with the taxing State, is fairly apportioned, does not discriminate against interstate commerce, and is fairly related to the services provided by the State."143 The first and fourth prongs of the test "limit the reach of state taxing authority so as to ensure that state taxation does not unduly burden interstate commerce." 144 The second and third prongs "prohibit

\footnotetext{
138. Id. at 306-08.

139. U.S. CONST. art. I, § 8, cl. 3.

140. Gibbons v. Ogden, 22 U.S. (9. Wheat.) 1, 13-17 (1824).

141. 430 U.S. 274, 279 (1977) (adopting a four-factor test for assessing tax laws against Commerce Clause challenge).

142. Quill, 504 U.S. at 310 .

143. Complete Auto, 430 U.S. at 279.

144. Quill, 504 U.S. at 313.
} 
taxes that pass an unfair share of the tax burden onto interstate commerce."145

The "substantial nexus" requirement of the Complete Auto test-the first prong-has created the most controversy. Some commentators suggest the only way to satisfy substantial nexus is through physical presence, such as a store or employees within a state. ${ }^{146}$ This argument, however, expands the Quill decision too far, especially when considering that Quill did not account for the potentials of the Internet and ecommerce. Without question, the Quill Court established that a retailer "whose only connection with customers in the [taxing] State is by common carrier" is free from the duty to collect taxes for that state. ${ }^{147}$ As sales have become less dependent on physical interactions, fewer businesses have the requisite substantial nexus with a state, and inevitably, states lose tax revenue.

Even the Court in Quill disagreed over what satisfied the "substantial nexus" requirement. In a lengthy and persuasive dissent, Justice White argues that physical presence in an economy is an archaic view of commerce. ${ }^{48}$ Justice White pointed to the many advantages remote sellers gain from doing business with residents of a state, even though they may never actually have a "physical presence" within that state:

These advantages include laws establishing sound local banking institutions to support credit transactions; courts to ensure collection of the purchase price from the seller's customers; means of waste disposal from garbage generated by mail-order solicitations; and creation and enforcement of consumer protection laws, which protect buyers and sellers alike, the former by ensuring that they will have a ready means of protecting against fraud, and the latter by creating a climate of consumer confidence that inures to the benefit of reputable dealers in mail-order transactions. ${ }^{149}$

145. Id.

146. Daniel Tyler Cowan, Recent Development, New York's Unconstitutional Tax on the Internet: Amazon.com v. New York State Department of Taxation \& Finance and the Dormant Commerce Clause, 88 N.C. L. REV. 1423, 1436 (2010) ("The Quill Court was clear: physical presence, in the form of 'a small sales force, plant or office' is required.” (quoting Quill, 504 U.S. at 315)). This statement by the Court is at best dicta because the court admits this area of law is a "quagmire" and that the rule is rather artificial. Quill, 504 U.S. at 315. Further, the Court's used this exact language: "Whether or not a State may compel a vendor to collect a sales or use tax may turn on the presence in the taxing State of a small sales force, plant, or office." Id. (emphasis added).

147. Quill, 504 U.S. at 315 (alteration in original) (quoting Nat'l Bellas Hess, Inc. v. Dep't of Revenue, 386 U.S. 754, 758 (1967)) (internal quotation marks omitted).

148. Id. at 327-28 (White, J., dissenting).

149. Id. at 328 . 
Justice White's dissent practically predicts the rise of e-commerce. The arguments he advances apply even more readily to today's society where many transactions occur digitally, without any type of physical interaction. In the almost twenty years since Quill, the opportunities for a remote seller to reap the benefits of a state without having any use-taxcollection responsibility toward that state have grown. Such opportunities have motivated states to develop the innovative approaches that require remote sellers to "pay" for these benefits.

As previously mentioned, the Appellate Division of the New York Supreme Court recently ruled on facial and as-applied challenges under the Due Process, Equal Protection, and Commerce Clauses to New York's affiliate law. ${ }^{150}$ The court held that the law, on its face, did not violate the Commerce Clause. ${ }^{151}$ First, the court found the requisite substantial nexus because the law imposes obligations on a remote seller "only where the [remote seller] enters into a business-referral agreement with a New York State resident, and only when that resident receives a commission based on a sale in New York." ${ }^{\text {152 }}$ The court emphasized that "passive advertising" would not satisfy the required substantial nexus, but solicitation by affiliates would. ${ }^{153}$ The law meets this requirement by allowing the remote seller to rebut the presumption of physical presence by proving all affiliates engaged only in advertising. ${ }^{154}$ A remote seller "merely has to include in its contract with the in-state vendor a provision prohibiting [the affiliate] from 'engaging in any solicitation activities...' and the in-state representative must provide an annual certification that it has not engaged in any prohibited solicitation."155 Therefore, the law does not violate the Commerce Clause because it imposes obligations only on remote sellers who contract with in-state residents and only when those residents engage in direct solicitation. ${ }^{156}$

The decision suggests that as long as an affiliate law requires solicitation, and not merely advertising, it will pass a facial Dormant Commerce Clause challenge. Problems may still arise, especially when a specific business challenges an affiliate law. As pointed out by the court

150. Amazon.com, LLC v. N.Y. State Dep’t of Taxation \& Fin., 913 N.Y.S.2d 129, 146 (N.Y. App. Div. 2010), aff'g as modified 877 N.Y.S.2d 842 (N.Y. Sup. Ct. 2009).

151. Id. at 138 .

152. Id.

153. Id. at $138-39$.

154. Id.

155. Id. (footnote omitted).

156. Id. 
in New York, when all of a business's affiliates only advertise and do not solicit business, the substantial nexus does not exist. ${ }^{157}$ Therefore, it is imperative that all affiliate laws have safeguards in place to guarantee that in-state representatives actually solicit business for the remote seller. New York safeguards businesses with affiliates engaged in purely advertising by allowing the remote seller "a ready escape hatch or safe harbor" through the rebuttable presumption of solicitation. ${ }^{158}$ Even with the safeguard in place, New York's law must still pass the as-applied challenge, which may require proving that thousands of affiliates did solicit business for their online retailers.

It is not entirely clear how a court would apply the Dormant Commerce Clause to Colorado's increased notification approach. In Colorado, the remote seller does not have the burden of collecting the use tax and only bears the burden of notifying consumers of purchases that are subject to the use tax. ${ }^{159}$ This notification burden differs greatly from the burdens recognized by the Court in Quill-the requirements of figuring, remitting, and collecting the use tax. ${ }^{160}$ Therefore, it is undecided how much of a burden the notification standards place on remote sellers and whether a "substantial nexus" would be required.

Nonetheless, Colorado's law likely survives a Dormant Commerce Clause challenge for two reasons. First, it does not require the business to calculate, collect, and remit use taxes. ${ }^{161}$ Under the Colorado law, a remote seller is not responsible for figuring and collecting the tax unless it chooses to do so to avoid the reporting requirements. ${ }^{162}$ A remote seller subject to the Colorado law has two responsibilities: keeping track of its sales shipped to Colorado addresses and notifying the purchaser and state of the sales. ${ }^{163}$ The law implicitly recognizes that figuring and collecting use tax is much more burdensome than the notification requirements; thus, Colorado allows the remote seller to collect the tax instead of notifying Colorado purchasers of their obligation to pay the tax.

157. Id. at $138-39$.

158. Id.

159. Colo. Rev. Stat. AnN. § 39-21-112(3.5) (West Supp. 2011).

160. See Quill Corp. v. North Dakota, 504 U.S. 298, 302 (1992) (citing N.D. CENT. CoDE § 5740.2-07 (Supp. 1991)).

161. Colo. Rev. Stat. AnN. § 39-21-112(3.5).

162. Id.

163. Id. 
Second, the Colorado law attempts to minimize the burdens placed on remote sellers. ${ }^{164}$ It includes a provision that allows a non-collecting retailer to use a generalized notification if it also faces the same reporting requirements in others states. ${ }^{165}$ If other states implement a similar type of notification law, then multi-state retailers face minimal compliance burdens. This is important because, as stated in Quill, the state must limit the burdens it places on the out-of-state businesses so as to avoid burdening interstate commerce. ${ }^{166}$ Because the law allows businesses to use the same notification in several states, Colorado has actively sought to diminish the burdens its law places on remote sellers. ${ }^{167}$

While the Colorado law only requires remote sellers to comply with the notification requirements, some of the regulated entities have asserted that the law "clearly intended to increase the compliance burden to a point where online retailers will be induced to 'voluntarily' collect Colorado sales tax." ${ }^{168}$ While this argument may have some merit, the holding in Quill undercuts it. The Court in Quill noted that required compliance with the various taxing jurisdictions, different definitions, and assorted exemptions imposed an undue administrative burden. ${ }^{169}$ Here, the business must comply only with reporting purchases to the state; there is nothing to keep track of outside of what the business already possesses, which is the consumer's name, addresses, and purchases. A court would be less likely to find an undue burden where a business must provide information that it already possesses. Even with these provisions in place, Colorado's law faces staunch opposition from remote sellers.

A recently filed lawsuit challenges Colorado's new law by arguing that it discriminates against out-of-state retailers and unduly burdens interstate commerce. ${ }^{170}$ The plaintiff alleges that the Colorado law discriminates against out-of-state retailers because they must spend time

164. Id.

165. Colo. CodE REgs. § 39-21-112.3.5(2)(e) (2010).

166. See Quill Corp. v. North Dakota, 504 U.S. 298, 313 (1992).

167. While this portion of the law is a proactive step, it retains limited value until other states implement laws requiring the same information as Colorado.

168. Amazon Reacts to Colorado Interest Sales Tax Measure by Firing Its Colorado Associates, HufFingtON Post (Mar. 8, 2010, 9:20 AM), http://www.huffingtonpost.com/2010/03/08/amazonreacts-to-colorado_n_490028.html (quoting Letter from the Amazon Assocs. Team to Colo.-Based Amazon Assocs. (Mar. 8, 2010)).

169. Quill, 504 U.S. at 313 n.6.

170. Direct Mktg. Ass'n v. Huber, No. 10-cv-01546-REB-CBS, 2011 WL 250556, at *3 (D. Colo. Jan. 26, 2011). 
and money to change their business practices to comply with the new law, while retailers located within Colorado are not subject to the same reporting requirements. ${ }^{171}$ Even though Colorado's law attempts to reduce the burdens placed on remote sellers, some burdens must inevitably fall on the remote seller in order to increase use-tax revenue. Colorado's law differs from other approaches, however, because the true burden-as specified in Quill as figuring, collecting, and remitting the use tax-falls on the consumer and not on the business.

A Dormant Commerce Clause analysis of the SSTP and SSUTA is unnecessary. ${ }^{172}$ The SSTP-formed in response to the Quill Court's calling on Congress to resolve the use-tax-collection dispute-by design avoids a Dormant Commerce Clause challenge. Because Congress has the authority to determine what burdens commerce, ${ }^{173}$ adoption of the SSUTA would indicate that Congress believes that the measure did not burden interstate commerce. Thus, if Congress required all states to adopt the SSUTA, no basis would exist to challenge it on Dormant Commerce Clause grounds. As previously discussed, however, the SSUTA and SSTP contain several flaws that make passage by Congress highly unlikely.

\section{Feasibility of Implementing State Approaches}

States that have enacted affiliate laws have encountered many implementation problems. With large retailers cutting ties with affiliates and eroding the required nexus, ${ }^{174}$ states have realized that the approach included unforeseen flaws. The affiliate laws' intention of taxing companies through independent contractors and affiliates-thus avoiding entity isolation issues-has backfired. This shows the main weakness of the affiliate laws: a remote seller can erode the nexus, which Part III.D discusses in more detail. Further, large remote sellers have almost unlimited resources to challenge these laws. As evidenced by the lawsuits and opposition to the affiliate laws, states have a long hill to climb before the approaches will achieve their goals.

171. Id.

172. Still, SSUTA's sourcing scheme potentially burdens interstate commerce and, thus, threatens its implementation. See Part III.C.

173. See Quill, 504 U.S. at 318.

174. See, e.g., Kopytoff, supra note 78, at B1 (describing how Amazon fired its in-state affiliates in Colorado, North Carolina, and Rhode Island). 
An aspect of the Colorado law that makes it superior to the affiliate laws is that the remote seller cannot exempt itself from the law by cutting ties with the state. Therefore, even if a company fires off all its affiliates within Colorado - as Amazon did ${ }^{175}$ - the remote seller would still face the notification requirements. Because Colorado based its notification requirements solely on the amount of sales, it avoided the problem of remote sellers eroding the nexus and eluding the requirements of the law.

On the other hand, Colorado will likely face consumer backlash against the law. The average individual consumer is likely entirely unaware of the use tax. Because the law makes consumers aware of taxes on purchases that for years went tax-free, opposition will likely grow. Some consumers might refuse to comply with the use tax despite the state's awareness of their purchases. If the courts ultimately uphold Colorado's law against a Commerce Clause challenge, then Colorado has a good chance to successfully implement the law-even if a substantial amount of opposition exists-because, in contrast to affiliate laws, neither remote sellers nor consumers has the power to avoid the law's requirements.

Implementation of the SSTP and SSUTA requires a single act of Congress for full implementation. In the twenty years since the Court in Quill called on Congress to regulate in the area of sales and use tax, ${ }^{176}$ Congress has not taken action. Therefore, although the SSTP is only one piece of legislation away from achieving its goal, congressional authorization appears unlikely. ${ }^{177}$ Twenty-four states have adopted the SSUTA and "more states are moving to adopt [it]." ${ }^{\text {178 }}$ If the SSTP counts as members a majority of U.S. states — or states with a majority of the U.S. population-then Congress might feel the pressure to act. Currently, insufficient pressure exists.

Besides a lack of congressional action, the SSTP and SSUTA face additional obstacles. The SSUTA contains serious flaws, which some commentators argue should prevent its nationwide implementation. ${ }^{179}$ The biggest debate about the SSUTA is the dispute between origin-based sourcing and destination-based sourcing. ${ }^{180}$ This problem arises because

\footnotetext{
175. Id.

176. Quill, 504 U.S. at 318.

177. See Swain, supra note 52, at 370.

178. About Us, supra note 98.

179. Henchman, supra note 12.

180. See John A. Swain \& Walter Hellerstein, The Streamlined Sales Tax Project and the Local Sourcing Conundrum, 104 J. TAX'N 230, 230-32 (2006). This distinction determines whether to
} 
"[w] hen the product is received by the purchaser at a business location of the seller, the sale is sourced to that business location."181 On the other hand, "[w]hen the product is not received by the purchaser at a business location of the seller, the sale is sourced to the location where receipt by the purchaser ... occurs, including the location indicated by instruction for delivery to the purchaser." 182 Many opponents argue that this structure is antithetical to one of the SSTP's stated goals: taxing like transactions alike. ${ }^{183}$ In effect, remote sellers must collect use taxes based on the customer's location, while stores with a physical presence in a state must collect tax in only one jurisdiction. ${ }^{184}$ Thus, remote sellers face a much greater burden-possibly enough to burden interstate commerce ${ }^{185}$ - and the problem addressed by the Court in Quill persists. ${ }^{186}$ The SSTP should resolve the sourcing problem to facilitate nationwide acceptance.

A second problem of the SSTP is that it allows states to bypass its rules. ${ }^{187}$ On the one hand, "the SSTP requires that all states have a uniform definition of clothing and tax all of it (or none of it) at the same rate." 188 Minnesota, however, imposed a separate "fur tax" on fur sales. ${ }^{189}$ "Rather than recognizing this as an end-run around tax uniformity, the SSTP upheld Minnesota's action."190 The SSTP only requires substantial compliance from states, ${ }^{191}$ and such minutiae likely did not bring the state out of compliance. For full implementation, the SSTP must take steps to actually reach uniformity and reduce the burdens placed on remote sellers. The aforementioned flaws justify Congress's complacency regarding the SSTP.

\footnotetext{
apply the tax of the originating jurisdiction or the destination jurisdiction. Id.

181. SSUTA §310(A)(1) (2011), available at http://www.streamlinedsalestax.org/uploads/ downloads/Archive/SSUTA/SSUTA\%20As\%20Amended\%2005-19-11.pdf.

182. Id. § 310(A)(2).

183. See, e.g., Henchman, supra note 12 (noting that the SSTP has "abandoned the notion of taxing like transactions alike” with its sourcing scheme).

184. Henchman, supra note 11 .

185. See generally Swain \& Hellerstein, supra note 180 (discussing origin- and destination-based sourcing, and prescribing several solutions to the problem).

186. Quill Corp. v. North Dakota, 504 U.S. 298, 312-15 (1992) (discussing how a state's use tax may unduly burden interstate commerce).

187. See Henchman, supra note 12.

188. Id.

189. Id.

190. Id.

191. SSUTA $\S \S 804,805$ (2011), available at http://www.streamlinedsalestax.org/uploads/ downloads/Archive/SSUTA/SSUTA\%20As\%20Amended\%2005-19-11.pdf.
} 
1. Hybrid Solution: States Implementing the SSUTA in Addition to Other Measures

Arkansas, North Carolina, and Rhode Island have all implemented affiliate taxes ${ }^{192}$ while still retaining full membership in the SSTP. ${ }^{193}$ Thus, a state with an affiliate law still maintains substantial compliance even though the tax contradicts the SSTP's main goals of uniformity and simplicity. As with Minnesota's fur taxes, the SSTP needs to stick to its guns. In other words, if it wants federal legislation, the SSTP should strongly consider requiring more uniformity from the states. Permitting state deviation undercuts the SSTP's goals and gives opponents a strong argument against implementation.

\section{Notification Requirements Cause Privacy Concerns}

Some of the approaches may also be prone to attack on privacy grounds. Colorado's law undoubtedly will face privacy challenges, ${ }^{194}$ and North Carolina has seen the effect firsthand. ${ }^{195}$ These privacy concerns arise from the states' gathering of details regarding purchases and consumers' wariness of the states' having the information. As evidenced in North Carolina, purchasers were afraid that the state would obtain "title-specific data on customer book purchases."196 The state's need for detailed information on purchases stems from the fact that it needs to determine if a purchase is taxable under that state's sales- and use-tax system. This issue arose in North Carolina when the state-in trying to determine Amazon's compliance with the law-requested consumer-purchase information from Amazon. ${ }^{197}$ While this issue arose in a different context from what Colorado may face, the information requested remains substantially similar. As one commentator has stated,

192. Henchman, supra note 76 .

193. State Info, STREAMLINED SALES TAX Gov'G BD., INC., http://www.streamlinedsalestax.org/ index.php?page=state-info (last visited Jan. 27, 2011).

194. Complaint at 19-23, Direct Mktg. Ass'n v. Huber, No. 1:10CV01546 (D. Colo. June 30, 2010), 2010 WL 2724158 (alleging, among other violations, that Colorado's notification law violates Colorado consumers' right to privacy under both the Colorado and U.S. Constitution).

195. Dan Cullen, Amazon.com Challenges North Carolina Over Sales and Use Tax Collection, AM. BOOKSELLERS Ass'N (Apr. 22, 2010), http://news.bookweb.org/news/amazoncom-challengesnorth-carolina-over-sales-and-use-tax-collection (discussing pending case brought in North Carolina and the privacy concerns raised over the new law).

196. Id.

197. Id. 
however, generalized information regarding purchases does not violate the First Amendment. ${ }^{198}$

Thus, in order for states to require remote sellers to collect use taxes-or, in the case of Colorado, to require the companies to report purchase information to the state- they must ensure that the information requested is not specific enough to raise privacy concerns. This should not be a problem because states generally require generic information in categories such as "books" or "food."199 In going forward, states must recognize that they cannot request every detail of a transaction, as this could "create a chilling effect on the free flow of information."200

\section{Approaches' Ability to Increase Revenue and Improve Use-Tax Compliance}

In analyzing these approaches, the fundamental question for states is whether the adopted approach will bring in more revenue. Several problems exist in determining how much revenue each approach has generated. First, none of the approaches have been in place long enough to create measureable revenue streams. Second, large retailers have repeatedly cut off all ties with affiliates in states that have imposed affiliate laws. ${ }^{201}$ Finally, some states have not spent the revenue or released statistics on their programs because they are waiting for the outcome of a lawsuit. ${ }^{202}$

Initial reports about state implementation of affiliate laws are worrisome. Rhode Island had not seen any increase in revenue from its law in the first six months after implementation. ${ }^{203}$ Compounding this problem is that Rhode Island and the other states that have implemented affiliate laws may actually lose revenue when large, remote sellers cut

198. Oren Teicher, the CEO of the American Booksellers Association, acknowledged that "the collection of general purchase information for purposes of use tax enforcement does not violate the First Amendment." Id.

199. As explained by a representative of the North Carolina Department of Revenue, the state "simply requested a representative of the type of product purchased, for example, 'book." Id.

200. Id. (quoting letter from Am. Booksellers Ass'n to Bev Perdue, Governor, State of N.C. (Apr. 22, 2010) (providing a template for members to use to contact the Office of the Governor)).

201. See, e.g., Kopytoff, supra note 78, at B1 (discussing Amazon's withdrawals from states that have enacted affiliate taxes).

202. See, e.g., Henchman, supra note 73 ("New York is collecting tax revenue but under a constitutional cloud, making it risky to spend it.”).

203. Ted Nesi, “Amazon Tax” Has Not Generated Revenue, ProvidenCE Bus. News (Dec. 21, 2009), http://www.pbn.com/detail.html?sub_id=2976531d0961\&page=1. 
ties with all of their in-state affiliates. ${ }^{204}$ The states' economies suffer because the in-state affiliates no longer receive commissions; which reduces their income tax and puts less money into the economy. This result makes it clear that remote sellers will do almost anything to avoid collecting use taxes and keep the façade of low prices intact. Therefore, affiliate laws will likely generate less revenue than expected because a remote seller can easily avoid the collection requirement. ${ }^{205}$

Colorado's notification law has several safeguards in place to decrease the chances of abuse by remote sellers and ensure that it collects as much revenue as possible. The law takes care to prevent abuse by businesses but strives to lessen the burdens placed on remote sellers. First, Colorado avoids the problem faced by states with affiliate laws because remote sellers cannot avoid the requirements by merely cutting ties with affiliates. ${ }^{206}$ Because a remote seller's affiliates do not trigger the notification requirements, Colorado's law is less likely to drive away business. Thus, even if a remote seller severs all ties with the state, the notification requirement still applies, provided the business meets the de minimis and other requirements. Despite this provision, Amazon, as it had in other states, cut all ties with Colorado affiliates immediately after the state's adoption of the law. ${ }^{207}$ This withdrawal—which undoubtedly decreased Amazon's revenue in Colorado-plainly shows the lengths to which remote sellers will go to avoid use-tax responsibility. Colorado has also safeguarded against abuse by a remote seller that attempts to practice forms of entity isolation. The law exempts a remote seller from the notification requirements when it makes less than $\$ 100,000$ in sales to Colorado residents. ${ }^{208}$ This $\$ 100,000$ includes sales by affiliates or "entities controlled by or under common control with the non-collecting retailer."209 Thus, a remote seller cannot avoid the notification requirements by funneling business through an affiliate or related entity.

Two other aspects of the Colorado law make certain that Colorado realizes the highest amount of revenue possible. First, Colorado attempts to take advantage of the fact that many remote sellers already have procedures in place to calculate use-tax liability. For these retailers, it

\footnotetext{
204. See id.

205. Id. (noting that "[f]or a company like Amazon there is little risk in pulling out of Rhode Island").

206. Colo. Rev. Stat. AnN. § 39-21-112(3.5) (West Supp. 2011).

207. Kopytoff, supra note 78, at B1.

208. COlo. Rev. Stat. AnN. § 39-21-112(3.5)(d)(I)(B).

209. COLO. CODE REGS. § 39-21-112.3.5(1)(e) (2010).
} 
may be less burdensome to collect the tax on each transaction instead of keeping records for all transactions and remitting the information to the purchaser and state. The Colorado law allows any retailer that collects and remits use tax to avoid the reporting requirements, ${ }^{210}$ which some argue is the true intent of the law. ${ }^{211}$

Second, Colorado's law also seeks to increase revenue by making consumers aware of their use-tax liability. The state likely intends to remedy the extremely low use-tax compliance rates of individuals and the Quill ruling's near guarantee that a state cannot require a remote seller to collect and remit use tax. As mentioned previously, Colorado avoids the burdens specifically decried by the Court in Quill: figuring, collecting, and remitting the use tax. ${ }^{212}$ Colorado has taken a proactive approach to increasing individual use-tax compliance. By notifying Colorado residents that the use tax applies to some of their purchaseswhile concurrently notifying them that the state has the information relating to their use-tax liability - the law places the pressure upon the individual to figure and remit the tax. Therefore, the compliance rates will likely rise in Colorado because of either increased individual awareness of the tax liability or fear of repercussions for noncompliance with the law. Either way, Colorado has moved the burden of use-tax collection from remote sellers-where the burden can almost never $\mathrm{lie}^{213}$ - to individuals, who before were only responsible for collection and remittance in theory, not in practice.

The SSTP has the ability to increase state revenue in tremendous amounts; however, until Congress acts, this revenue will go unrealized. The SSUTA currently contains no mechanism to elicit use-tax collection by remote sellers; it requires approval from Congress to achieve all of its goals. While the SSUTA possesses ample revenue opportunities for the future, voluntary membership in the SSTP will not increase revenue. As more states become members of the SSTP, the overall membership will approach a majority-either of the states or population-and gain support in Congress. The flaws of the SSTP and the SSUTA, however, make majority membership and congressional action unlikely in the near future.

\footnotetext{
210. Colo. Rev. StAT. ANN. § 39-21-112(3.5).

211. Amazon Reacts, supra note 168.

212. See Quill Corp. v. North Dakota, 504 U.S. 298, 313 (1992).

213. See id. at 317-18 (holding that a state cannot require a remote seller to collect and remit use taxes without a substantial presence of that remote seller within that state).
} 


\section{CONCLUSION}

This Comment analyzes the varied approaches that states have taken to increase use- and sales-tax compliance with remote sellers. While the approaches vary widely, they all have the same purpose: increase use-tax revenue in a constitutionally permissible way. Though nothing seems clear in this area of the law, states should coordinate their efforts against remote sellers who do not cooperate with use- and sales-tax-collection laws. The three separate approaches discussed each have merits and flaws. Each has faced staunch opposition by remote sellers and others.

The SSTP needs only congressional action to solve the entire usetax-collection dilemma. Because it contains several major flaws, however, majority membership and congressional approval remain unlikely. Without an affirmative act from Congress requiring the states to adopt the SSUTA, or something substantially similar, the SSTP is in limbo. Because of the dire state of the economy and the boom of ecommerce, states need the increased use-tax revenue now. The SSTP will not bring revenue to states in the near future, or possibly at all. Therefore, any state that desires to increase revenue will need to turn to a different approach—such as affiliate laws or increased notification standards.

For a state going out on its own, there are several problems as well. First, a state acting alone is not as strong as states that have banded together, especially when dealing with a national issue like interstate commerce. With only three states implementing affiliate laws, retailers dismiss these laws as unconstitutional and proceed to funnel their business and affiliates through other states to avoid the responsibility of use-tax collection. If more states followed the leads of Arkansas, California, Connecticut, Illinois, New York, North Carolina, and Rhode Island, then remote sellers would be less likely to cut ties with their affiliates, as they would be responsible for use-tax collection in more states and would have nowhere to isolate their advertising. Furthermore, an increase in the number of states that have enacted affiliate laws will increase awareness of the use tax among purchasers. This will cause more individuals to realize that they did not receive tax-free products; instead, they broke the law.

Finally, Colorado has taken the most proactive approach to increasing individual awareness of the use tax. The use-tax-collection burden in Colorado shifts from the business to the purchaser. Because purchasers are always liable for payment of the use tax, it seems appropriate that they now bear the burden of figuring, collecting, and 
remitting the tax. It will be interesting to see how Colorado residents react to these changes. While some may see it as increased taxes, others may see it as a burden and realize that the remote seller, and not the consumer, should bear responsibility for collection of the use tax. For any state seeking to increase use-tax revenue in the short term, Colorado's approach gives the most hope. First, because the law does not depend upon a business's having dispensable affiliates within a state, the business cannot cut ties with the state in order to avoid the notification requirements. Second, Colorado's law places fewer burdens upon the remote sellers. By only requiring notification and not requiring them to figure, collect, and remit the use tax, Colorado avoids burdens pointed out by the Court in Quill. ${ }^{214}$ Third, even if Colorado's law fails in some way, it undoubtedly will increase individual awareness of the use tax-likely allowing for measures to be taken in the future without as much opposition.

214. Id. at 313. 